\title{
Survey of Professional Attitudes toward Range Science Education and Training
}

\section{R. KIENAST AND C. J. SCIFRES}

Highlight: Questionnaires relative to range science education and training were completed by about 120 professionals in the discipline. Respondents were in general agreement that coursework in the social sciences should receive more emphasis in range curricula. Most respondents also stressed the ever-increasing need for development and refinement of communicative skills. Natural resource use, planning, and management was most frequently cited as an important future problem facing range workers. Expertise in public relations also rated high as a future need for rangemen. The majority of the respondents indicated that training undergraduates as land resource managers should be emphasized instead of utilizing curricula dominated by "strictly scientific aspects." Most respondents were optimistic concerning future employment possibilities for range majors with indications that future graduates might be in increasing demand for certain areas of industry and business.

This survey was stimulated by the theme of the Society for Range Management's 1972 meeting: "Range Resources and Society's Needs-A Look Ahead to the 21 st Century." The motive for such a theme is obvious. As do dedicated professionals in any discipline, range professionals are asking questions such as: Does our work fill the intended need? Are we working in the most fruitful direction? What changes in direction should we take to most effectively meet future needs? Are we adequately educating and training the rangemen of the future?

As Hervey (1964) stated, "What is being said today about range managers is a response to their effectiveness as they

At the time of writing the article, the authors were student and associate professor, respectively. Department of Range Science,
Texas A\&M University, College Station. Kienast presently is a graduate assistant, Utah State University, Logan.

The authors are grateful to Dr. C. L. Leinweber, Dr. M. M. Kothmann, Mr. James Bluntzer, and Mr. David Polk, Jr., for their helpful criticism in developing this manuscript. The encouragement of many who suggested formal publication of these results after their presentation to the Society in Washington, D.C. is also acknowledged.

Manuscript received April 24, 1972. presently perform their duties with the benefit of yesterday's university training." Hervey recognized the need for our discipline to respond to perpetual change in the objectives of society. This need has been amplified in the last 5 years with intense public interest in the fate of natural resources.

There is no dependable, analytical method for accurately forecasting educational needs to meet future professional challenges. However, predictive information can be assembled in a qualitative manner by utilizing expert opinion. $\mathrm{Ob}$ jectives of this survey were to seek professional opinion regarding (a) important attributes of range graduates seeking employment, (b) work experience which augments formal training in range science, (c) coursework background considered most desirable in range education programs, and (d) future problems and needs to consider in range curricula. The respondents also were asked their opinion as to future job opportunities for range science graduates.

\section{Materials and Methods}

A form consisting of 11 basic questions was sent to Soil Conservation Service (SCS), university and college, Bureau of Land Management (BLM), Forest Service (FS), and ranch management personnel. Questions in the survey included: (1) relative importance of selected personal and academic characteristics in employing a range science graduate, (2) importance of work experience to the undergraduate range major, (3) the role of research in undergraduate training, (4) opinions as to areas of important coursework, present deficiencies and any suggested educational changes, (5) future management problems for rangemen, and (6) areas of work which will probably utilize range graduates and an opinion as to future employment potential.

About 130 questionnaires were mailed with over a $90 \%$ response. The forms were identified only as to the respondent's present source of employment. The lowest number (13) were received from ranchers.

Questionnaires were grouped for summary according to employer of the respondent. However, respondents were asked to answer only on the basis of their personal philosophy. Questionnaires were sent to central administrative offices of agencies. Recipients who did not wish to participate were requested to pass the form to an interested person in the same organization. The questions were of three basic types. In the first type, respondents were asked to rank several factors in order of importance. Respondents listed important factors or attributes in answer to a specific request in the second type of question. The third type of question requested discussion of an issue.

As expected, not all respondents wished to answer all questions. Therefore, responses were summarized by source and 
presented as a percentage of the total number of responses for each question.

\section{Results and Discussion}

Results are discussed from an integrated viewpoint that resulted from discussion by undergraduate range science students and university professors. Several upperclassmen and professors in addition to the authors analyzed and debated the responses to each question.

\section{Attributes of Candidates for Employment}

Most surveyed (except ranchers) felt that nature of coursework should be the primary attribute considered in selecting a potential employee from among range science majors (Table 1). This, of course, reflects the basic need of the college student for exposure to sound subject matter. Although other attributes of the graduate may be highly desirable, his coursework background must adequately prepare him to meet job requirements. Range science graduates need a unique background developed to deal with a basic natural resource. Therefore, it is very important that university personnel continue to take special care in developing and monitoring educational programs. Proper advice and direction may be decisive in utilization of electives for necessary breadth and strength in the student's program.

Only ranchers rated work experience as the most important criterion in selecting an employee (Table 1). This can be attributed partly to their broad job requirements and to a basic belief that work experience best qualifies an individual for ranch management. Nature of coursework and grades were important to ranchers but only as indicators of technical aptitude for coping with practical problems.

SCS personnel ranked grades fourth, behind nature of coursework, personal recommendations, and work experience as important attributes for potential employees (Table 1). This response was interpreted as indicating relative academic performance: that the difference between an $A$ and a strong $B$ student would not weigh heavily if coursework was sound. Conceivably, a broad, sound, subjectmatter base would be more important than an unblemished transcript of lessdesirable courses.

Only ranchers ranked impression during interview in the top three attributes for employment (Table 1). Differences in personal appearance were apparently considered important only in deciding be-

Table 1. Responses (\%) of professional workers relative to attributes considered most important for range science majors seeking employment.

\begin{tabular}{lrrrrrr}
\hline \hline Attributes & SCS & Univ. & BLM & FS & Ranchers & Avg \\
\hline Grades & 13 & 25 & 20 & 27 & 17 & 20 \\
Work experience & 16 & 5 & 10 & 18 & 33 & 16 \\
General background & 8 & 4 & 0 & 5 & 8 & 5 \\
Applicant's age & 3 & 0 & 0 & 0 & 0 & $<1$ \\
Nature of coursework & 30 & 27 & 40 & 32 & 9 & 28 \\
Personal recommendations & 14 & 23 & 20 & 9 & 0 & 13 \\
Personal appearance & 5 & 5 & 0 & 0 & 8 & 4 \\
Impression during interview & 8 & 11 & 10 & 9 & 25 & 13 \\
College or university attended & 3 & 0 & 0 & 0 & 0 & $<1$ \\
\hline
\end{tabular}

Table 2. Responses (\%) of professional workers relative to type of experience felt to be most important to range science majors seeking employment.

\begin{tabular}{lrrrrrr}
\hline \hline Type of experience & SCS & Univ. & BLM & FS & Ranchers & Avg \\
\hline General & 6 & 0 & 0 & 0 & 23 & 6 \\
Practical (such as ranching) & 33 & 20 & 10 & 20 & 38 & 24 \\
$\begin{array}{l}\text { Summer training (as with } \\
\quad \text { federal agency) }\end{array}$ & 48 & 41 & 50 & 40 & 31 & 42 \\
$\begin{array}{l}\text { Research technician (part-time) } \\
\text { Extension Service technician }\end{array}$ & 11 & 26 & 20 & 30 & 0 & 17 \\
$\quad($ part-time) & 2 & 13 & 20 & 10 & 8 & 11 \\
\hline
\end{tabular}

Table 3. Responses $(\%)$ from professional workers toward the value of undergraduates' participating in research projects.

\begin{tabular}{lcrrrrr}
\hline Opinion & SCS & Univ. & BLM & FS & Ranchers & Avg \\
\hline Research beneficial & 62 & 84 & 80 & 100 & 57 & 77 \\
Research not beneficial & 21 & 16 & 0 & 0 & 29 & 13 \\
Depends on type of research & 17 & 0 & 20 & 0 & 14 & 10 \\
\hline
\end{tabular}

tween two equally-qualified potential employees. As with grades, it is assumed that extremes would have a direct affect on an employer's decision. General background and college or university attended were usually considered least important by respondents.

Undoubtedly, an employer's judgment is usually not based on any single attribute but on overall qualifications of the candidate. However, these responses do indicate relative importance of attributes most often considered by employers.

\section{Work Experience}

Application of classroom principles may be facilitated by furnishing the range science student with practical work experience. Lehman (1966) felt that "the emphasis should be on the principles of the basic sciences, and less on technical elaborations." However, the impact of basic knowledge is best realized when students practice its direct application. While attaining practical experience, the student may be exposed to practicing professionals and an array of viewpoints.

Most respondents indicated that summer training programs afforded the most important work experience for range science majors (Table 2). Ranchers, however, considered practical ranching experience and summer training almost equally important. Obviously, maximum involvement in the ranching operation during the formative stages of his career is desirable for a potential ranch manager.

Most respondents felt that exposure to research programs, such as summer work with an agricultural experiment station, was beneficial (Table 3) if (a) research was of such a nature that the student could associate the results with a practical range management situation, (b) the student functioned directly in the research rather than performed only menial tasks, and if (c) association with the research was not conducive to narrowing the student's point of view. Most respondents felt the present role of research in student training should be maintained. SCS respondents indicated that graduates should be able to interpret research results. Respondents generally indicated that research experience would be best spent examining broad-range problems rather than in emphasizing specific points of concern. 
Table 4. Responses (\%) of professional workers relative to the most important areas of coursework for proper preparation of range science students.

\begin{tabular}{lrrrrrr}
\hline \hline \multicolumn{1}{c}{ Coursework } & SCS & Univ. & BLM & FS & Ranchers & Avg \\
\hline Agricultural engineering & 0 & 0 & 7 & 0 & 8 & 3 \\
Agrostology & 8 & 4 & 0 & 0 & 0 & 2 \\
Animal science & 13 & 13 & 0 & 0 & 17 & 9 \\
Biological science & 9 & 12 & 12 & 4 & 0 & 7 \\
Ecology & 24 & 25 & 19 & 28 & 0 & 19 \\
Economics and business & 4 & 5 & 0 & 0 & 25 & 7 \\
Genetics & 0 & 0 & 0 & 0 & 8 & 2 \\
General management & 4 & 0 & 0 & 18 & 0 & 4 \\
Mathematics & 0 & 4 & 0 & 9 & 0 & 3 \\
Plant science & 1 & 4 & 6 & 5 & 0 & 3 \\
Range management & 13 & 9 & 6 & 5 & 17 & 10 \\
General resource management & 0 & 4 & 0 & 0 & 8 & 2 \\
Social science and communication & 16 & 13 & 38 & 13 & 9 & 18 \\
Soils & 8 & 7 & 6 & 0 & 8 & 6 \\
Statistics & 0 & 0 & 0 & 18 & 0 & 4 \\
Wildlife management & 0 & 0 & 6 & 0 & 0 & 1 \\
\hline
\end{tabular}

Table 5. Most important management problems (\%) facing range sciences in the next decade.

\begin{tabular}{lrrrrrr}
\hline \hline Problem areas & SCS & Univ. & BLM & FS & Ranchers & Avg \\
\hline Adjusting to change & 11 & 4 & 0 & 6 & 10 & 6 \\
Basic ecology & 5 & 2 & 8 & 6 & 0 & 4 \\
Brush control & 3 & 4 & 0 & 0 & 10 & 3 \\
Chemical usage & 0 & 0 & 0 & 0 & 5 & 1 \\
Business and economics & 12 & 6 & 0 & 6 & 15 & 8 \\
Environmental understanding & 12 & 19 & 25 & 32 & 10 & 20 \\
Genetics of range plants & 0 & 0 & 0 & 0 & 5 & 1 \\
Plant-soil relations & 5 & 0 & 0 & 0 & 0 & 1 \\
Public relations & 8 & 17 & 8 & 0 & 10 & 9 \\
Natural resource use, & & & & & & \\
planning, and management & 39 & 44 & 34 & 50 & 30 & 39 \\
Surface mining & 0 & 0 & 8 & 0 & 0 & 2 \\
Watershed management & 5 & 0 & 17 & 0 & 5 & 5 \\
Others & 0 & 4 & 0 & 0 & 0 & 1 \\
\hline
\end{tabular}

\section{Coursework and Formal Training}

As Box (1964) stated, "The range profession must act to see that all students who call themselves rangemen have training acceptable to the profession." Descriptions of coursework considered important by professionals should be helpful in developing range science curricula. Guidelines published by Sampson (1954) reflected the classical approach to range education. Several areas he emphasized are reflected in the 1971 survey.

Respondents were in general agreement concerning the need for expanding coursework in the social sciences and communication (Table 4). Emphasis on communicative skills probably indicates the everincreasing role of range workers in dealing with rather broad segments of society. This basic need, communicating with clientele, was emphasized by Dyksterhuis (1953). Deficiencies in communication were also noted by Tisdale (1956) and Hervey (1964). Yet, communications courses are now an integral part of most range curricula. Perhaps a new approach should be considered. Instead of risking over-emphasis of social and communica- tive skills to range students and possibly reducing their time for developing a strong technical base, perhaps an effort should be made to educate society more effectively concerning our basic natural resource-rangeland. ${ }^{1}$ Then too, effective communication is an art usually refined through personal and professional maturity and experience.

Traditionally, ranchers have felt that rangemen should receive more general training in range management (Weaver, 1953). Ranchers in this survey considered economics and business of primary importance (Table 4). Hervey (1964) suggested incorporation of business courses into range curricula some 7 years ago. Ranchers considered animal science and range management the second most important areas of coursework (Table 4). Most ranchers pointed out in this survey that the average range graduate is usually well grounded in range management and animal science.

${ }^{1}$ This argument was posed by a journal reviewer during final stages of manuscript preparation. It was suggested that perhaps courses in resource management should be offered by the public school system. In the opinion of the authors, the suggestion has considerable merit.
They indicated that agricultural engineering, genetics, soils and general resource management are also important areas of coursework.

FS respondents indicated a need for more coursework in statistics and general management in range curricula (Table 4). A review of current offerings in several university catalogs indicated that statistics is required of undergraduates in a few range departments. However, biometry is probably included in vegetation evaluation courses taught in most range curricula.

Respondents were also asked to list present areas of deficiency in range curricula. FS and university personnel felt that ecology was one area of deficiency among range majors. Some suggested replacing a portion of current plant ecology courses with animal and general ecology courses. In four university curricula surveyed, requirements in ecology ranged from 7 to 13 hours. The university with highest requirements listed 10 hours in general ecology and 3 hours in formal study of range ecosystems. Most other universities stressed plant ecology. FS personnel indicated that range science students were deficient in proper use of resources related to rangeland. The only area of science indicated as deficient by SCS respondents was a basic understanding of soils.

\section{Future Problems Facing Range Workers}

Natural resource use, planning, and management were frequently cited as the most important future problems for range workers (Table 5). Understanding of environmental problems occurred second most frequently as an important future concern.

Many respondents felt that adjusting to continual and rapid change might be critical for contemporary range professionals. Range science graduates must be familiar with new techniques and methods as they are reported to assure their rapid and effective implementation.

In 1953, Dyksterhuis suggested that 'Perhaps 'men and their ways' should become an object of formal as well as informal study by the range man." Evidently, such understanding is still needed. Public relations was rated high in the present survey as a major future concern for range science graduates (Table 5). Only FS personnel did not indicate public relations activities as a future problem. Obviously, the profession will fulfill its role only if graduates of the future are able to "sell" the public on necessary 
Table 6. Response (\%) of professional workers concerning areas of future emphasis necessary to meet requirements for range scientists.

\begin{tabular}{|c|c|c|c|c|c|c|}
\hline Areas of future emphasis & SCS & Univ. & BLM & FS & Ranchers & Avg \\
\hline \multicolumn{7}{|l|}{ Multiple-use, long-range planning } \\
\hline $\begin{array}{l}\text { Basic training in business and } \\
\text { economics }\end{array}$ & 7 & 10 & 9 & 0 & 0 & 5 \\
\hline Flexibility and broadening & & & & & & \\
\hline of training base & 6 & 7 & 9 & 9 & 0 & 6 \\
\hline $\begin{array}{l}\text { Training as land and range } \\
\text { resource managers instead }\end{array}$ & \multicolumn{5}{|c|}{ Training as land and range } & \\
\hline of as scientists & 44 & 27 & 37 & 9 & 75 & 38 \\
\hline Soils and range hydrology & 10 & 0 & 0 & 0 & 0 & 2 \\
\hline $\begin{array}{l}\text { Ecosystem management and } \\
\text { basic ecology }\end{array}$ & 10 & 0 & 27 & 0 & 0 & 8 \\
\hline Practical summer training & & & & & & \\
\hline for students & 3 & 3 & 0 & 0 & 0 & 1 \\
\hline Environmental problems & 0 & 23 & 0 & 18 & 0 & 8 \\
\hline Systems analysis and modeling & 0 & 3 & 0 & 18 & 0 & 4 \\
\hline Livestock production efficiency & 0 & 0 & 0 & 0 & 25 & 5 \\
\hline
\end{tabular}

procedures for proper rangeland management. Hervey (1964) indicated “. . . a need for top-notch range management 'salesmen' who know what they are talking about." Present survey results indicate that such a need has not diminished. Hervey (1964) questioned: "Are we graduating technicians who are without training in administration and public relations?" and issued ". . . a plea for inclusion in the curriculum of carefully selected courses that will teach the potential range manager how to sell his ideas and how to administer his program." A quick scan of range curricula of four major universities showed three without required coursework in sociology and the remaining one with 11 undergraduate hours required in sociology and humanities. Evidently, Dr. Hervey's and Dr. Dyksterhuis' original points, in view of the results of this survey, should be restated even more emphatically.

\section{Future Roles of Range Professionals}

Areas usually indicated for future emphasis were (a) training as land resource

managers with less emphasis on "strictly scientific aspects" and (b) capabilities in multiple-use of natural resources integrated with long-range planning, including urban interests (Table 6). These two areas comprised over $50 \%$ of the responses regardless of source. Dyksterhuis (1953) analyzed range education as having "... quite generally the objective of developing scientists rather than artisans, artificers, or artists." The expressed need for more general practitioners in range was indicated from responses to our survey. Hervey (1964) suggested two plans at the Master of Science level for range science. One without thesis requirements was designed to develop the broadly-trained resource manager.

\section{Employment Potential}

Most respondents felt that employment opportunities with private ind ustry such as real estate, banking, and counseling services will increase for range graduates (Table 7). This same trend was indicated by Box (1964) 8 years ago. The lack of

Table 7. Responses (\%) of professional workers relative to potential areas of employment for future range science graduates.

\begin{tabular}{lrrrrrr}
\hline \multicolumn{1}{c}{ Area } & SCS & Univ. & BLM & FS & Ranchers & Avg \\
\hline $\begin{array}{l}\text { Environmental and } \\
\quad \text { related agencies }\end{array}$ & 10 & 3 & 8 & 0 & 0 & 4 \\
$\begin{array}{l}\text { Governmental agencies } \\
\text { Land-use planning and }\end{array}$ & 37 & 34 & 34 & 18 & 30 & 31 \\
$\quad$ general management & 27 & 45 & 42 & 46 & 20 & 36 \\
$\begin{array}{l}\text { Private industry (real estate } \\
\quad \text { banking, etc.) }\end{array}$ & 12 & 9 & 8 & 9 & 20 & 12 \\
$\begin{array}{l}\text { Range-related foreign } \\
\quad \text { assignments }\end{array}$ & 0 & 0 & 0 & 9 & 10 & 4 \\
$\begin{array}{l}\text { Ranching } \\
\text { Research }\end{array}$ & 7 & 3 & 8 & 18 & 20 & 11 \\
Teaching & 2 & 3 & 0 & 0 & 0 & 1 \\
\hline
\end{tabular}

respondents from industry is a definite weakness of this survey.

In the opinion of the respondents, fewer range science graduates will be needed for research and teaching in the immediate future (Table 7). Further, the ranching industry may utilize more range science graduates as ranching operations are consolidated into larger units. However, ranching will probably continue to provide a minor outlet, relative to numbers, for employment of range graduates.

Most respondents were optimistic about the future availability of jobs for range science graduates. None felt availability of jobs would decrease, and the majority of BLM (83\%) and FS (71\%) respondents predicted an increase in job opportunities. About half of SCS and university respondents felt that employment possibilities will increase in the next few years. All replies concerning future availability of jobs were apparently based on the state of the economy. University, BLM, and FS respondents predicted that more range science majors would be needed to fill future jobs in land-use planning and general management (Table 7).SCS participants indicated a continuing need for graduates in governmental agency work.

As pointed out by Hervey (1964), the impression left by today's range managers and scientists reflects on yesterday's university training. Papers written by range workers in the last decade indicating training and educational needs are, in most cases, germane to today's curricula needs. The present survey poses more questions than it answers. However, these results may provide some insight for range educators to formulate more effective teaching and training programs regardless of present concepts and direction.

\section{Literature Cited}

Box, T. W. 1964. Trends in range management education. J. Range Manage. 5:237-241.

Dyksterhuis, E. J. 1953. Some notes and quotes on range education. J. Range Manage. 6:295-298.

Hervey, D. F. 1964. The challenge of the future as viewed by educators in range schools. $J$. Range Manage. 17:119-121.

Lehman, A. 1966. A technical education isn't enough. J. Range Manage. 19:171-172.

Sampson, A. W. 1954. The education of range managers. J. Range Manage. 7:207-212.

Tisdale, E. W. 1956. Range management education. II. College training in range management. J. Range Manage. 9:218-219.

Weaver, G. E. 1953. Range education from the rancher's viewpoint. J. Range Manage. $6: 307-308$. 